\section{Ethylene Gas for Defoliation of Hydrangeas}

\author{
Theo J. Blom and Richard B. Smith \\ Horticultural Research Institute of Ontario, Vine land Station, Ont., \\ LOR 2E0, Canada
}

Additional index words. Hydrangea macrophylla

Abstract. Summer-grown Hydrangea macrophylla subsp. macrophylla var. macrophylla (Thunb.) were exposed for 1 week to $\mathrm{C}_{z} \mathrm{H}_{4}$ at $0,0.5,2.0,5.0,50$, or $500 \mu \mathrm{l} \cdot$ liter ${ }^{-1}$ in dark storage at $16 \mathrm{C}$ for defoliation before cold storage. The number of leaves remaining per shoot for all cultivars decreased with $\mathrm{C}_{2} \mathrm{H}_{4}$ concentration, and $>5 \mu \mathrm{l} \mathrm{C}_{2} \mathrm{H}_{4} /$ liter was effective in defoliating 'Kasteln', 'Mathilda Gutges', and 'Todi' but not 'Merritt's Supreme'.
Field-grown florists' hydrangeas are normally defoliated before cold storage to reduce foliar diseases. Chemical defoliants have either no registration and a low $\mathrm{LD}_{50}$ or show negative side effects (Bailey, 1990; Kofranek and Leiser, 1958). As an $\mathrm{C}_{2} \mathrm{H}_{4}$ source, mature apples (3 liter apples $/ \mathrm{m}^{3}$ of storage space) are effective for defoliating hydrangeas held in a fairly airtight enclosure. Because the optimal $\mathrm{C}_{2} \mathrm{H}_{4}$ concentration for hydrangea defoliation is unknown, we determined this quantity for defoliation and its effect on subsequent plant growth.

\section{Materials and Methods}

At the end of Oct. 1991 and 1992, summer-grown plants, in 1.6-liter pots, of four florists'hydrangeacultivars(Kasteln,Mathilda Gutges, Merritt's Supreme, and Todi) from two commercial growers (Gregory and Westbrook) in southern Ontario were taken ment was at stage 5 (Litlere and Stromme, 1975) for all cultivars. The first week of November, plants were exposed for 1 week to sprayed once with 2-butyne- 1,4-diol (butyne diol; BD) at $10 \mathrm{~g} \cdot$ liter $^{-1}$. Two plants per cultivar and grower were placed in open totes stackedinsidea300-liter, 150-pm-thick, sealed polyethylene bag. Predetermined volumes of $\mathrm{C}_{2} \mathrm{H}_{4}$ were injected into each bag to obtain the appropriate treatment concentration, verified by a gas chromatography and adjusted daily. All bags contained hydrated lime for $\mathrm{CO}_{2}$ removal.Oxygen and $\mathrm{CO}_{2}$ concentrations were checked every second or third day with a portable $\mathrm{CO}_{2}-\mathrm{O}_{2}$ analyzer (Nova 305; Hamilton, Canada). Compressed $\mathrm{O}_{2}$ was added to the bag to obtain $20.8 \% \mathrm{O}_{2}$, and $\mathrm{CO}_{2}$ con-

Received for publication 30 July 1993. Accepted for publication 9 Dec. 1993. We appreciate the support of Oregon Propagating Co., Brookings, Ore.; Westbrook Greenhouses, Grimsby, Canada; and Gregory Greenhouses, St. Catharines, Canada. The cost of publishing this paper was defrayed in part by the payment of page charges, Under postal regulations, this paper therefore must be hereby marked advertisement solely to indicate this fact. from the field. Terminal flower bud develop$\mathrm{C}_{2} \mathrm{H}_{4}$ at $0,0.5,2.0,5.0,50$, or $500 \mu \mathrm{l} \cdot$ liter $^{-1}$ or centrations remained near $0 \%$. The $\mathrm{C}_{2} \mathrm{H}_{4}{ }^{-}$ treated plants were held in one room, and nontreated (control) and BD-treated plants were held in a separate room. Both rooms were dark, ventilated with $\mathrm{C}_{2} \mathrm{H}_{4}$-free air, and kept at $16.0 \pm 1.0 \mathrm{C}$.

Three days after the 1-week $\mathrm{C}_{2} \mathrm{H}_{4}$ exposure, the number of leaves ( $>4 \mathrm{~cm}$ in length) that had to be physically removed (remaining leaves) and the total number of shoots were recorded for each plant. Defoliation was considered effective if the remaining number of leaves per shoot per plant was <1.0. After leaf removal, plants were stored for 6 weeks in a room at $5.0 \pm 1.0 \mathrm{C}$ then moved to a double acrylicgreenhousein mid-January. Plants were placed randomly on a subirrigation system using troughs and fertigated with $0.75 \mathrm{~g} 18 \mathrm{~N}-$ $0 \mathrm{P}-10 \mathrm{~K}-9 \mathrm{Ca}-1 \mathrm{Mg}$ per liter at each watering. The hydrangeas were forced at $18-20 \mathrm{C}$. At flowering (pollen shown on the true flowers), shoot length and leaf surface area of the upper most fully expanded leaf pair on two shoots and the diameter and number of mature (fully expanded and pigmented), immature (green), and aborted inflorescences per plant were determined. The experiment consisted of a completely randomized design with each bag as an experimental unit and was run twice. We analyzed the results as a split-plot experiment with year and replication as the main sources of variation; the $\mathrm{C}_{2} \mathrm{H}_{4}$ concentration, cultivar, and grower, and their interactions were the subplot variables. Regression curves for the $\mathrm{C}_{2} \mathrm{H}_{4}$ concentration and the contrast analysis between $\mathrm{BD}$ and $\mathrm{C}_{2} \mathrm{H}_{4}$ were determined for the variables.

\section{Results and Discussion}

As none of the interactions between the independent variables were significantly different, only the means of the main variables are presented (Table 1). The number of leaves
Table 1. Leaves remaining on four cultivars of field-grown hydrangeas from two growers after plants were exposed for 1 week to $\mathrm{C}_{2} \mathrm{H}_{4}$ or a single spray with $\mathrm{BD}$ and the effect of these chemicals on the number of mature and immature inflorescences per plant following 6 weeks at $5 \mathrm{C}$ then greenhouse forcing at $18-$ 20C. Data represent means for two consecutive years.

\begin{tabular}{|c|c|c|c|}
\hline Variable & $\begin{array}{l}\text { Leaves remaining/shoot } \\
\text { after } \mathrm{C}_{2} \mathrm{H}_{4} \text { treatment }{ }^{2}\end{array}$ & $\begin{array}{c}\text { No. mature } \\
\text { inflorescences }\end{array}$ & $\begin{array}{c}\text { No. immature } \\
\text { inflorescences }^{y}\end{array}$ \\
\hline \multicolumn{4}{|l|}{ Year } \\
\hline 1 & 1.72 & 4.50 & 0.67 \\
\hline 2 & 1.46 & 4.63 & 0.56 \\
\hline $\mathrm{LSD}_{0.05}$ & NS & NS & NS \\
\hline \multicolumn{4}{|l|}{ Source } \\
\hline Gregory & 1.44 & 4.67 & 0.69 \\
\hline Westbrook & 1.73 & 4.47 & 0.54 \\
\hline $\operatorname{LSD}_{0.05}$ & 0.17 & NS & NS \\
\hline \multicolumn{4}{|l|}{ Cultivar } \\
\hline Kasteln & 1.44 & 4.59 & 0.74 \\
\hline Mathilda Gutges & 1.22 & 6.05 & 0.83 \\
\hline Merritt's Supreme & 2.36 & 4.09 & 0.53 \\
\hline Todi & 1.32 & 3.54 & 0.37 \\
\hline LSD $_{0.05}$ & 0.24 & 0.35 & 0.28 \\
\hline \multicolumn{4}{|l|}{ Defoliant } \\
\hline \multicolumn{4}{|l|}{$\mathrm{C}_{2} \mathrm{H}_{4}\left(\mu \mathrm{l} \cdot\right.$ liter $\left.^{-1}\right)$} \\
\hline 0 (control) & 2.58 & 4.20 & 0.98 \\
\hline 0.5 & 2.43 & 4.54 & 0.65 \\
\hline 2 & 1.97 & 4.71 & 0.44 \\
\hline 5 & 0.97 & 4.47 & 0.62 \\
\hline 50 & 0.73 & 4.71 & 0.55 \\
\hline 500 & 0.65 & 4.77 & 0.47 \\
\hline \multicolumn{4}{|l|}{ BD $\left(g \cdot l i t e r^{-1}\right)$} \\
\hline 10 & 1.83 & 4.80 & 0.56 \\
\hline \multicolumn{4}{|l|}{ Significance $^{x}$} \\
\hline $\mathrm{C}_{2} \mathrm{H}_{4}$ & $\mathrm{~L}^{* * *} \mathrm{Q}^{* * *}$ & NS & NS \\
\hline $\mathrm{C}_{2} \mathrm{H}_{4}$ vs. BD & $* * *$ & NS & NS \\
\hline Control vs. $\mathrm{C}_{2} \mathrm{H}_{4}$ & $* * *$ & $* *$ & $* * *$ \\
\hline
\end{tabular}

'Remaining number of leaves $\left(>4.0 \mathrm{~cm}\right.$ long) were counted 3 days after the end of $\mathrm{C}_{2} \mathrm{H}_{4}$ treatment or 7 or 10 days after BD application.

${ }^{y}$ After forcing at $18-20 \mathrm{C}$.

${ }^{\times} \mathrm{L}=$ linear; $\mathrm{Q}=$ quadratic

*s. * **. ${ }^{* * *}$ Nonsignificant or significant at $P \leq 0.05,0.01$, or 0.001 , respectively. 
remaining per shoot for all cultivars decreased with increasing $\mathrm{C}_{2} \mathrm{H}_{4}$ concentration $(\mathrm{y}=2.08-$ $0.0318 \times$ concentration $+0.0000579 \times$ concentration $\times$ concentration). Ethylene at 25 $\mu \mathrm{l} \cdot$ liter $^{-1}$ was effective in defoliating 'Kasteln', 'MathildaGutges', and 'Todi' but not 'Merritt's Supreme'. The calculated optimum concentration for defoliation was $275 \mu 1 \cdot$ liter $^{-1}$. BD was less effective than $\mathrm{C}_{2} \mathrm{H}_{4}$ at $>5 \mu 1 \cdot$ liter $^{-1}$. The plant source showed a small but significant difference and was due probably to the difference in maturity of the terminal buds.

Treatments of $\mathrm{C}_{2} \mathrm{H}_{4}$ reduced the number of immature inflorescences and increased that of mature inflorescences compared to the control plants (Table 1). Ethylene did not affect flowering date, number of aborted inflorescences, leaf surface area, stem length, or flower diameter (data not shown). These results are contrary to studies in which ethephon resulted in reduced growth after forcing (Shanks, 1969; This and Buxton, 1976).

Thus, gaseous $\mathrm{C}_{2} \mathrm{H}_{4}$ at $5-10 \mu \mathrm{l} \cdot$ liter $^{-1}$ at $16 \mathrm{C}$ for 1 week in darkness was an effective alternative to BD at $10 \mathrm{~g} \cdot \mathrm{liter}^{-1}$ or the use of apples for defoliating 'Kasteln', 'Mathilda Gutges', and 'Todi' at minimal cost, and there were no negative effects on plant quality after forcing. 'Merritt's Supreme' may require a longer exposure or a higher temperature during $\mathrm{C}_{2} \mathrm{H}_{4}$ treatment.

\section{Literature Cited}

Bailey, D.A. 1990. Gibberellic acid enhances chemical defoliation of hydrangeas. HortScience 25:580.

Kofranek, A.M. and A.T. Leiser. 1958. Chemical defoliation of Hydrangea macrophylla Ser.Proc. Amer. Soc. Hort. Sci. 71 :555-562.

Litlere, B. and E. Stromme. 1975. The influence of temperature, daylength, and light intensity on flowering in Hydrangea macrophylla (Thunb.) Ser. Acts Hort. 51 :285-298.

Shanks,J.B.1969.Someeffectsandpotential uses of ethrel on ornamental crops. HortScience 4:56-58.

Thia,B. and J. Buxton, 1976. Influence of ethephon spray on defoliation and subsequent growth on Hydrangea macrophylla Thunb. HortScience 11:487488. 